\title{
The Global Knowledge Value Chain on Sustainability: Addressing Fragmentations through International Academic Partnerships
}

\author{
Bettina Schorr ${ }^{1, *} \mathbb{D}$, Marianne Braig ${ }^{1}$, Barbara Fritz ${ }^{1}$ and Brigitta Schütt ${ }^{2}$ \\ 1 Institute for Latin American Studies, Freie Universität Berlin, Rüdesheimer Str. 54-56, 14197 Berlin, Germany; \\ marianne.braig@fu-berlin.de (M.B.); barbara.fritz@fu-berlin.de (B.F.) \\ 2 Physical Geography, Department of Earth Sciences, Freie Universität Berlin, Malteser Str. 74-100, Haus H, \\ 12249 Berlin, Germany; brigitta.schuett@fu-berlin.de \\ * Correspondence: bettina.schorr@fu-berlin.de; Tel.: +49-30-838-58544
}

Citation: Schorr, B.; Braig, M.; Fritz, B.; Schütt, B. The Global Knowledge Value Chain on Sustainability: Addressing Fragmentations through International Academic Partnerships. Sustainability 2021, 13, 9930. https:// doi.org/10.3390/su13179930

Academic Editors: Maki Ikegami, Iain Patton and Marc A. Rosen

Received: 16 July 2021

Accepted: 1 September 2021

Published: 3 September 2021

Publisher's Note: MDPI stays neutral with regard to jurisdictional claims in published maps and institutional affiliations.

Copyright: (c) 2021 by the authors. Licensee MDPI, Basel, Switzerland. This article is an open access article distributed under the terms and conditions of the Creative Commons Attribution (CC BY) license (https:// creativecommons.org/licenses/by/ $4.0 /)$.

\begin{abstract}
While research on universities' role in sustainability transitions has flourished in recent years, explorations into the potential of academic internationalization for the promotion of sustainability transitions are still rare. This article aims at contributing to this incipient literature by emphasizing an underexplored property of international academic networks and transnational academic cooperation: their potential to break disciplinary and geographical barriers in the global debates on how transitions towards sustainability can be achieved. When realizing this potential, international partnerships are able to provide more comprehensive knowledge to inform sustainability transitions while shaping sustainability transitions in various places at the same time. This article pursues three objectives: First, it introduces the concept of the "global knowledge value chain on sustainability" and explores its value as a heuristic to understand global knowledge production relevant for sustainability transitions. Furthermore, it identifies two fragmentations in this chain resulting from global inequalities and specific dynamics within the global science community. Second, it confirms empirically the fragmentations of this global knowledge value chain on sustainability. Third, it provides good practice ideas on how international academic partnerships can overcome these fragmentations by drawing on the authors' experience with the international partnership "trAndeS-Postgraduate Program on Social Inequalities and Sustainable Development in the Andean Region" carried out by the Institute of Latin American Studies of Freie Universität Berlin and the Department of Social Sciences of the Pontificia Universidad Católica del Peru (PUCP).
\end{abstract}

Keywords: academic cooperation; global knowledge value chains; higher education; inequalities; internationalization; sustainability transitions

\section{Introduction}

While sustainability studies in general and research on universities' role in sustainability transitions in particular have flourished in recent years, explorations into the potential of academic internationalization for the promotion of sustainability transitions are still rare. The incipient literature argues that internationalization can promote sustainability by diffusing relevant knowledge, facilitating processes of mutual learning, enhancing intercultural sensitiveness, and allowing the pooling of scarce resources $[1,2]$.

This article aims at contributing to this nascent strand of research by emphasizing a property of international academic networks and transnational academic cooperation still underexplored: their ability to reduce disciplinary and geographical barriers in the global debates on transitions towards sustainability. To make this point, we introduce the concept of the "global knowledge value chain" related to sustainability and identify at least two fragmentations in this chain. We then propose a view of universities as knowledge brokers 
enabling the global circulation of different types of sustainability-relevant knowledge by means of international partnerships.

We argue that this potential is important for the promotion of sustainability because it is capable of providing a more comprehensive, interdisciplinary, and multi-spatial knowledge to inform sustainability transitions. As outlined in this article, this type of knowledge production is particularly important in the face of sustainability problems linked to globalization. International partnerships can also generate a wider impact by informing sustainability transitions in various places at the same time, especially in those places hosting the institutions involved in the partnerships. Last but not least, when bringing together universities from countries of diverse socio-economic background and with diverging resources for teaching and research, they can produce significant effects on higher education systems lacking resources to provide high-quality and internationally embedded education and research. In addition, they facilitate access to the global debates on sustainability which in itself can have important spill-over effects by extending curricula and research agendas of lecturers and researchers.

This article pursues three objectives: First, to introduce the concept of the "global knowledge value chain on sustainability" and explore its value as a heuristic to understand global knowledge production relevant for sustainability transitions. Second, to visualize empirically the fragmentations of this global knowledge value chain on sustainability; and third, to provide good practice ideas on how international academic partnerships address these fragmentations and aim at their reduction.

The paper proceeds as follows: First, we present our data and methods (Section 2). Section 3 summarizes the state of the art and presents our central concepts: the global knowledge value chain on sustainability and its fragmentations. Subsequently, in Section 4 we discuss empirical evidence on the two fragmentations we have identified: the disciplinary and the spatial one. In Section 5, we present some ideas on how international partnerships of universities may address these fragmentations by fostering interdisciplinary social science research on the topic of sustainability and addressing the fragmented landscape of knowledge production. In this section, we draw on our experience with an international partnership of the Institute of Latin American Studies of Freie Universität Berlin and the Department of Social Sciences of the Pontificia Universidad Católica del Peru (PUCP) entitled "trAndeS-Postgraduate Program on Social Inequalities and Sustainable Development in the Andean Region". Section 6 concludes with some final reflections including public policy recommendations for the Higher Education sector.

\section{Data and Methods}

We have used different strategies to provide empirical evidence for the argument of this paper. First, to demonstrate the disciplinary bias in sustainability research we have conducted a bibliometric study of publications in the Web of Science (WoS) data base. We searched for English articles published between 2005 and 2020 containing the terms sustainability or sustainable development. We then used the WoS tools to break down the overall sample into different disciplines. For our second argument, the spatial fragmentation of knowledge, we have mapped the publications and/or research projects of five universities in the Andean region with which we maintain cooperative relations in the context of our project trAndeS: Universidad de San Martin de Tarapoto, Peru; Universidad San Antonio de Abad in Cusco, Peru; Universidad de Cuenca, Ecuador; Universidad Mayor de San Andrés in La Paz, Bolivia; and Universidad Nacional de San Marcos in Lima, Peru. This selection corresponds to three provincial universities (San Martin, Cusco and Cuenca), two in Peru, one in Ecuador, and two universities in capital cities: the public universities Universidad Mayor de San Andrés (UMSA) in La Paz, Bolivia and Universidad Nacional de San Marcos (UNSM) in Lima, Peru.

Since we had to rely on public information self-reported on the webpages of these universities, we had to deal with some variation in data quality. In the case of UMSA, UNSM, and Cuenca, we collected the sustainability related publications of researchers or 
units with which we maintain cooperation: the postgraduate center, Centro de Investigación de Desarrollo (CIDES), at UMSA; the economic and political science department at UNSM; and the research groups for regional development and space and demography at Universidad de Cuenca. For the case of San Martin, individual publications were not available. Instead, we mapped all research projects of academic staff with institutional or external funding reported on the webpage of the Universidad de San Martin. For the case of the Universidad San Antonio de Abad de Cusco, neither projects nor individual publications are reported separately on the website. Instead, we mapped publications in the following journals: Cambio Climático en los Andes Tropicales, Revista de la Facultad de Derecho y Ciencias Sociales, El Antoniano, Q'euña, and Ambiente, Comportamiento y Sociedad, from 2010 until 2020, depending on availability. This mapping is not meant to be exhaustive, but to provide selective evidence for our argument of the spatial knowledge fragmentation. In Section 3 we rely on descriptive statistics and data generated in the operations of our project "trAndeS-Postgraduate Program on Social Inequalities and Sustainable Development in the Andean Region".

\section{State of the Art and Conceptual Framework}

\subsection{Sustainability and Internationalization in Higher Education}

Research has broadly confirmed that universities are, in several ways, important promoters of sustainability [3]. As an indicator, in recent years sustainability studies have grown to a differentiated academic field in its own right [4] and universities are conceived of as "living labs" where sustainability innovations can thrive and be subjected to testing [5]. Beyond research, universities have been found to promote sustainability by means of teaching and training [6,7], by introducing sustainability as a guiding campus principle [8-10] and promoting a sustainable campus management [11-14], and by organizing outreach activities with external stakeholders such as local communities or city administrations [15-17]. Regarding the latter, the regional transition literature investigates when and how universities may be able to shape sustainability transitions at a wider regional level [18].

More recently, scholars have also started to explore how academic internationalization and transnational cooperation among universities contribute to promote sustainability $[1,2,19]$. The literature argues that internationalization can promote sustainability in different ways: transnational networks provide channels to diffuse relevant knowledge, they facilitate processes of mutual learning, they enhance intercultural sensitiveness and allow the pooling of often scarce resources. More specifically, this incipient strand of research has advanced conceptual reflections on the characteristics and different types of international academic networks and differences in governance structures [1] as well as the strategies and instruments they use [2,20].

A property of international networks so far barely explored is their ability to break down barriers which prevent specific types of knowledge to circulate and actors to participate in the global debates on sustainability transitions. We argue that, when realizing this potential, international academic collaborations are capable of providing a more comprehensive view on sustainability relevant phenomena. In addition, they can facilitate access to the global debates on sustainability to academic institutions in countries with weak higher education systems and for those universities lacking resources to provide high-quality education and (internationalized) research. We develop this argument in the next section by introducing the concept of the global knowledge value chain on sustainability and discussing its fragmentations.

\subsection{The Global Knowledge Value Chain on Sustainability and Its Fragmentations}

The debate on how to transition towards a sustainable world should be a global debate for at least two reasons. First, achieving sustainability corresponds in many aspects to a global undertaking that requires simultaneous actions all over the world. The most prominent example of a sustainability related phenomenon requiring global action is global 
climate change. Because the climate is influenced by forces stemming from different sources all over the world (fire clearing in the Amazon region, oil extraction in the Arab region (and elsewhere), industrial pollution everywhere, but particularly by the industrialized countries of the Global North), global action is required in order to contain or mitigate it. Moreover, sustainability problems are often of a similar nature, so that even places located in very different parts of the globe may learn and benefit from each other's knowledge productions.

Secondly, several sustainability problems are the result of global interdependencies [21]. A large number of the persistent sustainability problems in specific places are caused by factors external to their immediate local or regional environment. In order to develop sustainable solutions to these challenges, we need to understand these interdependencies and causal relationships.

For the sake of illustration, we offer three examples: global climate change is a case in point, again. Climate change is caused mainly by the industrialized, "developed" nations in the Global North. According to the Human Development Report 2011 [22], the average person in a rich country accounts for more than four times the carbon dioxide emissions (one of the drivers of climate change and global warming) of a person in a poor country-and about 30 times the carbon dioxide emissions of a person in a very poor country (see also [23]). However, while less wealthy nations have contributed the least to global climate change, they are bearing a disproportionate share of its costs in terms of environmental degradation. These countries experience the greatest loss in rainfall and the greatest increase in its variability with implications for agricultural production and livelihoods. Rising temperature also reduces biodiversity by de-stabilizing ecosystems with consequences ranging from soil degradation to plagues.

The second example concerns reactions to climate change and measures to reduce carbon emissions. In Europe, one of these strategies involves the increased use of lithium as an energy storage envisioned to promote the transition to renewable energies. However, mining lithium (for example in the Andean region of Argentina, Bolivia, and Chile) to fuel the European energy transitions has come at high environmental and social costs. These include water scarcity, desertification, as well as soil and air contamination, which affect the livelihoods of the communities living nearby the extraction sites [24,25]. Likewise, social conflicts around the extraction of lithium has increased considerably spurring political instability, violence, and repression [26].

A third and related example is global value chains based in resource extraction $[27,28]$. These chains tend to be shaped by a globally unequal division of labor: the poor countries extract and export primary resources and the rich countries process, trade, and consume processed goods. The result is an unequal distribution of benefits and costs: The actors at the upper end of the production process (in the rich countries) gain the lion's share of the profits, while the lower end that provides the primary resources earns much less [29]. As mentioned in the case of lithium, local communities bear a whole series of negative consequences from environmental degradation [30,31] to social conflict as well as economic crisis and political instability [32-39]. Other examples in this area involve the large-scale production of so called "superfoods" popular among environmentally minded individuals in the Global North, such as quinoa, açai, and avocados. Notwithstanding them being marketed as good for the environment, these in fact produce considerable environmental damage in the Global South, such as water scarcity, soil degradation, and deforestation, as well as social and economic problems [40-42].

We have mentioned these examples to sustain that in order to appropriately evaluate any strategy of sustainability - or sustainable development so far-the possible impact of global interdependencies should be assessed. To grasp this global nature of sustainability debates, we advance the concept of global knowledge value chains. For this, we build on the classical definition of global value chains by Gereffi and others as "the full range of activities that firms and workers perform to bring a product from its conception to end use and beyond" [43]. The transfer not only of tangible goods, but also of different 
types of knowledge, is a key part of global economic interactions. Thus, global value chain relations also involve the interplay of different modes of knowledge transmission and development [44]. Accordingly, we define a global knowledge value chain as the full range of intellectual tasks by which knowledge is produced and intertwined at the local, regional, and global levels required to comprehensively inform a specific desirable state or phenomena. One such chain concerns knowledge for transitions towards sustainability. We understand the "global knowledge value chain" related to sustainability as an idealtypical global network that fosters a productive encounter among insights from different disciplines and locations. These combine to form a pool that provides comprehensive, meaningful, and policy relevant knowledge for sustainability transitions in the regions forming part of a globalized world.

While the potential of this chain to provide high quality knowledge and comprehensive information is high, in practice this global chain is fragmented. Given the existence of pronounced and increasing global inequalities and specific dynamics within the global science community, we argue that at least two fragmentations of the global knowledge value chain on sustainability can be identified. One fragmentation results from a significant bias within sustainability studies which tend to focus on issues related to conservation and resource protection. In contrast, the impact of economic, social, and political factors on opportunities for sustainability is far less studied, which led Boström to qualify the social dimension of sustainability as "the missing pillar" [45] that has been "marginalized by a sustainability agenda that is historically rooted in specific forms of environmentalism [ ... ]" [46]. However, ecological integrity cannot be disconnected from human behavior, values, and practices. It is culturally embedded and depends on political processes and the extent and quality of economic wellbeing [47]. Sustainability or sustainable development are mediated by a broad variety of economic, social, and political processes which are generally characterized by unequal power relations. This observation coincides with the critique that research on environmental sustainability often has a focus on technical solutions without considering the impact of context, particularly power relations, on their proper implementation or their opportunities for success [48].

The second fragmentation is based in specific geographic locations and the ensuing lack of access to resources which afflicts many universities, particularly in the Global South. While a broad variety of higher education institutions (HEI) in emerging markets and developing countries do provide research on local issues, including problems regarding sustainability in their local environment, this kind of knowledge production often does not circulate beyond the local level, and does not participate sufficiently in international forums to shape global debates. We refer to this as the fragmented spatial distribution of knowledge production. We define knowledge production as spatially fragmented when two conditions are met: First, knowledge is produced about phenomena that take place in the socio-spatial surroundings of a university and that are important for its local community. Second, this specific knowledge is unable to "travel", i.e., to connect to and shape regional and global academic debates. This kind of research often is not published in English, is mostly not comparative, and instead focuses on one single local case, rendering generalizations difficult; they are often not written in accordance with the customs, methodological considerations, and/or format of the dominant academic journals published in English. In this way, this knowledge is not designed nor equipped to circulate beyond the specific local level, and therefore cannot contribute to international debates regarding sustainability transitions, even if it could bring important and relevant insights.

As pointed out before, for a variety of reasons, fragmented knowledge production is particularly pronounced in the Global South. These include the general lack of public investment in the higher education sector and structural inequalities which privilege large universities in the capitals or private sector universities and discriminate against smaller institutions, in particular those located outside the big urban centers of their countries [49].

In particular, universities in rural areas have little emphasis on research and are only marginally embedded into global debates and internationalized research and teaching. 
At the same time, due to their location and proximity to problems often studied from a distance, they are potentially capable of producing valuable knowledge on local and regional processes and problems. On the other hand, universities in marginal regions often play an important role, as they represent one of the few stable institutions capable of providing advice and knowledge over time. This special type of university often serves as a local or regional hub for applied research, but with a rather limited focus in geographical terms, and in terms of knowledge diffusion beyond the immediate surroundings. This is expressed in publications on local phenomena, often published as grey literature or in local journals, edited and published by the respective university, and mostly in their domestic language (in our case: Spanish). The specific form of publishing (local publications; grey literature, languages other than English) does not comply with today's international standards of publishing in peer reviewed, internationally ranked journals in English and therefore reduces their visibility - and thus the inclusion of the respective scientists into the international scientific community [50,51].

In sum, in this section we have argued that in our globalized world, debates on sustainability benefit in many instances from a global perspective. We sustain this understanding by introducing the concept of the global knowledge value chain on sustainability which we define as the full range of intellectual tasks by which sustainability relevant knowledge is produced and intertwined at the local, regional, and global levels. Subsequently we have argued that this chain is fragmented, in the sense that disciplinary boundaries and spatial barriers prevent specific types of knowledge from participating in the global knowledge chain. The disciplinary fragmentations stem from a bias in sustainability research which tend to conflate sustainability with issues of conservation and resource protection while neglecting the importance of social and political factors. The spatial fragmentation is reflected in the difficulties of specific universities in participating in global debates because of linguistic barriers, the subjects treated, the ways they publish, and the outreach of their research. In the following two sections, we sustain empirically the disciplinary and spatial fragmentations of the global knowledge value chain on sustainability that we have conceptualized here.

\section{Empirical Explorations on the Fragmentations of the Global Knowledge Value Chain on Sustainability}

\subsection{Disciplinary Fragmentation: The Neglect of "Brown Issues"}

We argue that the first type of fragmentation of the global knowledge value chain on sustainability results from a disciplinary bias which conflates sustainability with issues of conservation and resource protection. Political, social, and economic factors shaping transitions towards sustainability tend to be neglected. This bias is confirmed by our exploration of the Web of Science database. The WOS database reveals a general and continuous growth of publications on the topics of "sustainable development" or "sustainability" in all disciplines since the early 2000s (Figure 1). Since 2005, the annual number of publications referring to the topics "Sustainable Development" or "Sustainability" has experienced a linear increase of approximately 1000 per year (2005: 2730, 2014: 12,039). With the launch of the UN 2030 Agenda in 2015, the publications referring to the topics "Sustainable Development" or "Sustainability" surged, reflecting the prominence of the present UN development strategy. Currently it varies annually between c. 3000-4000. 


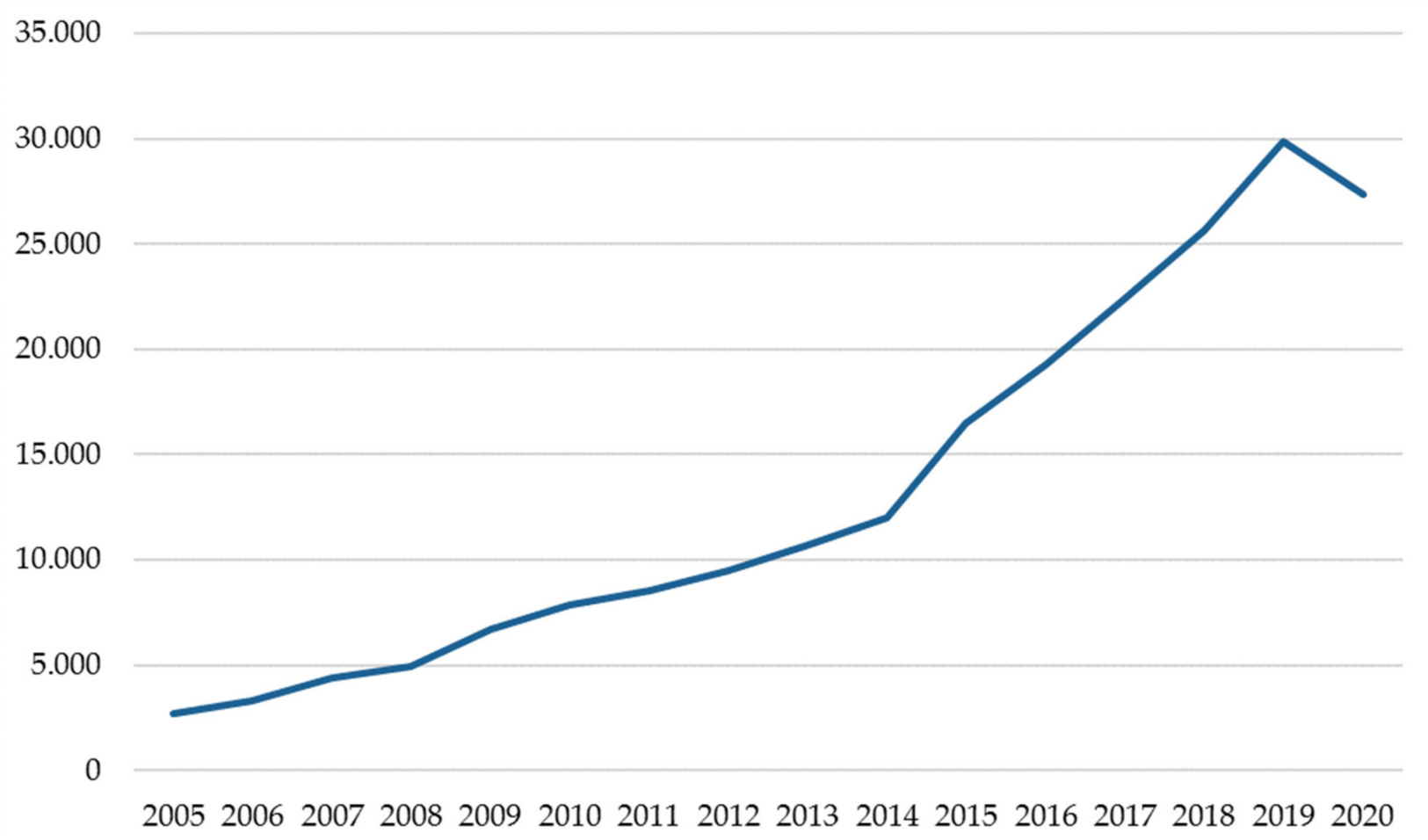

Figure 1. Annual number of publications between 2005 and 2020 referring to the topics "Sustainable Development" or "Sustainability" (title, keywords, abstract). Source: Own elaboration with data from Web of Sciences.

The disciplinary breakdown of these publications (Figure 2) shows that the topics of sustainability and sustainable development are mostly covered by the environmental sciences including engineering. In contrast, the number of publications referring to sustainability or sustainable development originating from the social sciences as the disciplines concerned with economic, political, and social issues is lower. From the social sciences, only economics and management studies show a middle position in the ranking, followed by geography and a category WoS calls "Interdisciplinary Social Sciences". The core social science disciplines of political science, sociology, and anthropology are far less concerned with these topics, or at least do not register their studies (in terms of key words or titles) as contributing to the debate on sustainability or sustainable development.

Our analysis of publication counts documents that "green issues" of biodiversity, conservation, and "green technology" have received the bulk of attention, while the so called "brown issues" [52] such as poverty, social inequality, and weak or dysfunctional public institutions are only rarely addressed. Of the various "brown issues", poverty has probably attracted the bulk of attention. Social inequality in research though is seldomly connected to the phenomena of sustainability and sustainable development, as shown in the analysis of WoS registered publications (Figure 3). This has changed only most recently, especially after the launching of the UN Agenda 2030 and the 17 Sustainable Development Goals (SDG). For the first time ever, a UN development strategy explicitly mentioned inequality as a barrier to development and mandated its reduction with SDG No. 10 [53]. However, while often limited to stating the existence of discrimination and exclusion as well as their effects, an analytical perspective on social inequalities must place power and wealth—not just poverty and exclusion—at the center of attention and identify the mechanisms through which both shape the opportunities for sustainable development or sustainability at the local, regional, national, or global levels [54]. This perspective is especially relevant in the so-called Global South, where rates of inequality tend to be much higher than in OECD countries. 


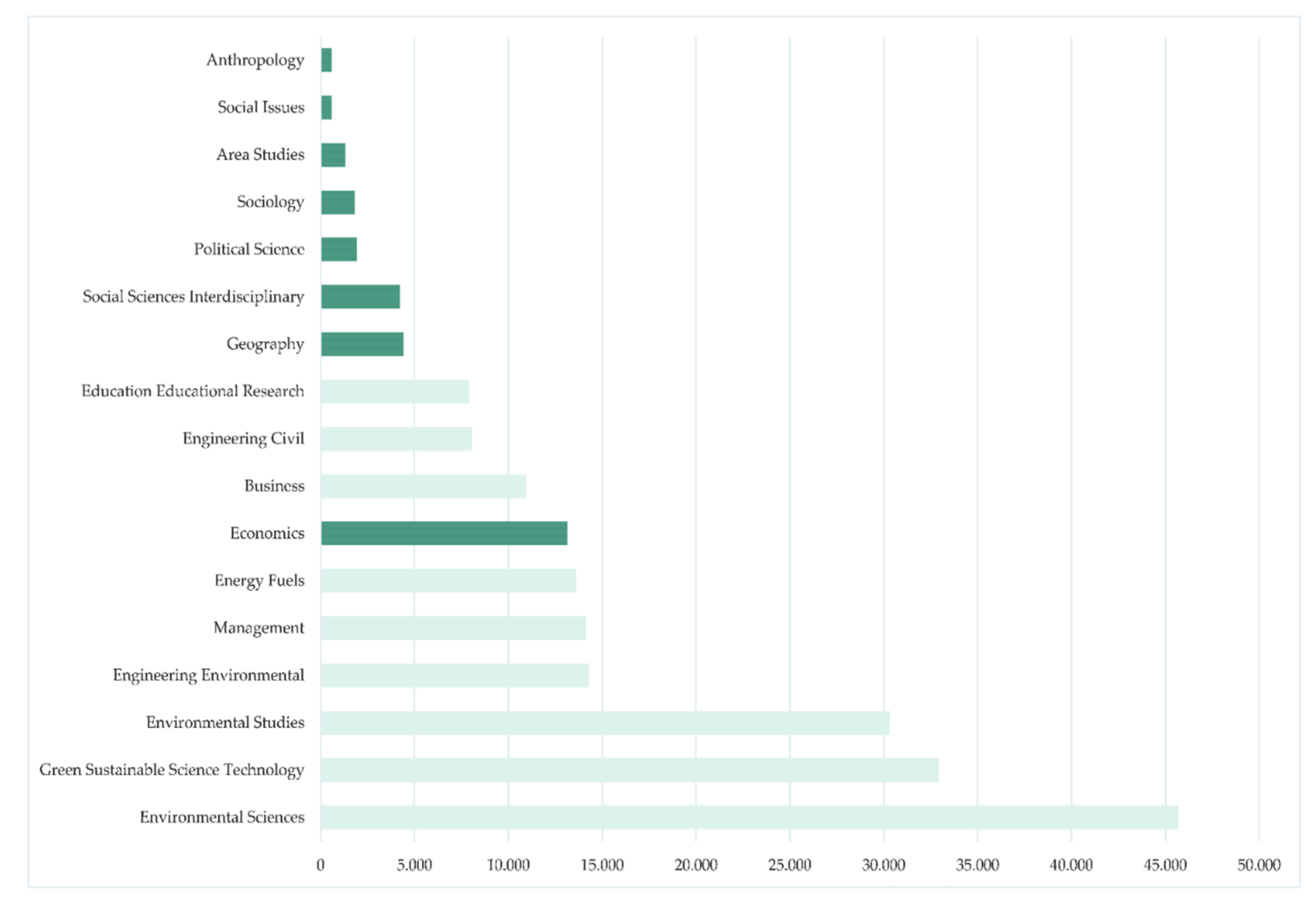

Figure 2. Disciplinary assignments of publications containing the topics "sustainable development" or "sustainability" between 2005-2020. Source: Own elaboration with data from Web of Sciences. Dark green bars highlight social sciences disciplines.

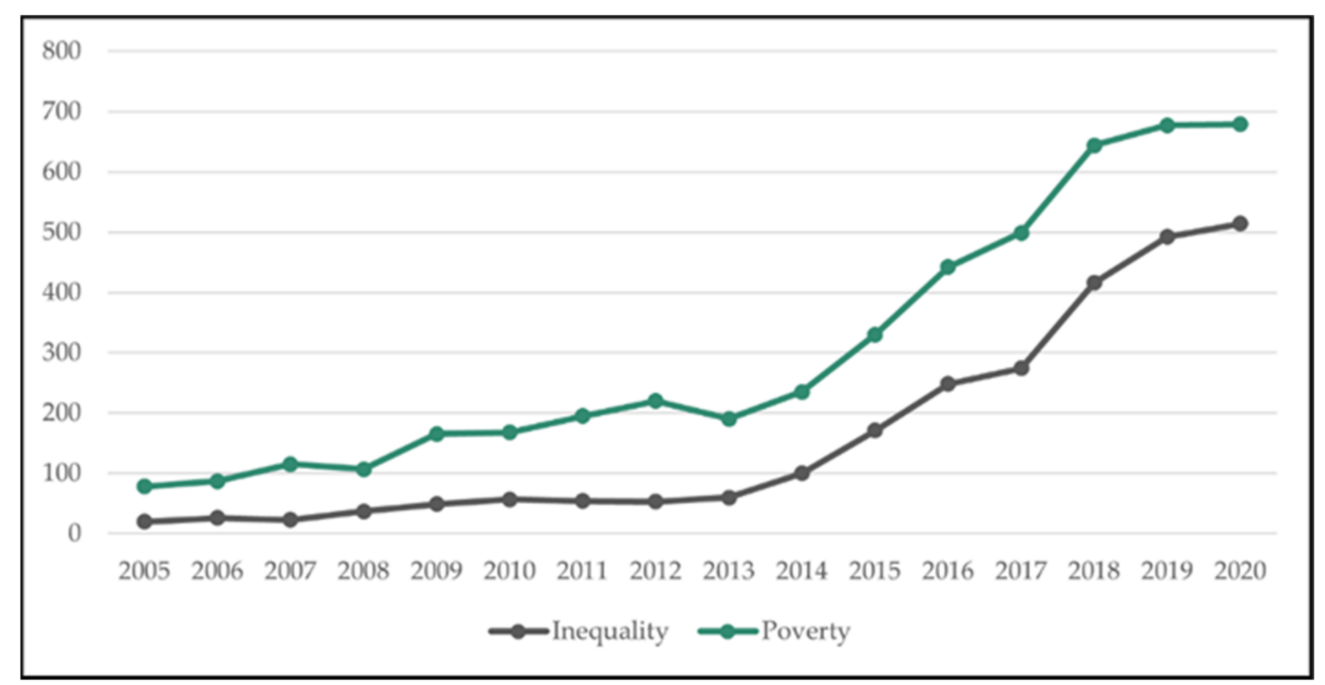

Figure 3. Publications in all disciplines containing the topics "sustainable development" and "sustainability" and "poverty" or "inequality", 2005-2020. Source: Own elaboration with data from Web of Sciences. 


\subsection{The Spatial Fragmentation of Knowledge: Evidence from the Andes}

The analysis of the publications of the five Andean universities support our understanding of the spatial fragmentation of knowledge production on sustainability and sustainable development between 2005 and 2020, although with certain variation (see Table 1 for a summary).

Table 1. Summary of empirical findings on local knowledge fragmentation.

\begin{tabular}{|c|c|c|c|c|c|c|}
\hline & & UNSM, Peru & $\begin{array}{c}\text { Universidad de San } \\
\text { Antonio de Abad de } \\
\text { Cusco, Peru }\end{array}$ & $\begin{array}{l}\text { Universidad de } \\
\text { San Martin, Peru }\end{array}$ & $\begin{array}{c}\text { UMSA CIDES } \\
\text { Bolivia }\end{array}$ & $\begin{array}{l}\text { Universidad de } \\
\text { Cuenca, Ecuador }\end{array}$ \\
\hline \multicolumn{2}{|c|}{ Number of publications: } & 125 & 105 & $\begin{array}{l}48 \text { (research } \\
\text { projects) }\end{array}$ & 78 & 73 \\
\hline \multirow{4}{*}{ Language: } & Spanish & 122 & 103 & 48 & 68 & 37 \\
\hline & English & 2 & 1 & 0 & 7 & 36 \\
\hline & Portuguese & 1 & 1 & 0 & 2 & 0 \\
\hline & Italian & 0 & 0 & 0 & 1 & 0 \\
\hline \multirow{7}{*}{ Spatial focus: } & Local & 0 & 39 & 38 & 9 & 7 \\
\hline & Regional & 0 & 0 & 1 (Amazonia) & 0 & 0 \\
\hline & National & 58 & 25 & 0 & 35 & 54 \\
\hline & International & 26 & 16 & 0 & 23 & 9 \\
\hline & Theoretical & 40 & 25 & 0 & 10 & 3 (and methods) \\
\hline & Laboratory & 0 & 0 & 9 & 0 & 0 \\
\hline & No data & 1 & 0 & 0 & 1 & 0 \\
\hline \multirow{9}{*}{ Publications: } & $\begin{array}{c}\text { Book ed. } \\
\text { international }\end{array}$ & 9 & 0 & \multirow{9}{*}{ / } & 7 & 11 \\
\hline & $\begin{array}{c}\text { Book ed. } \\
\text { university own }\end{array}$ & 20 & 0 & & 22 & 6 \\
\hline & $\begin{array}{c}\text { Books ed. others } \\
\text { national }\end{array}$ & 0 & 0 & & 16 & 4 \\
\hline & $\begin{array}{l}\text { University own } \\
\text { journals }\end{array}$ & 0 & 105 & & 15 & 0 \\
\hline & $\begin{array}{l}\text { Other national } \\
\text { journals }\end{array}$ & 25 & 0 & & 1 & 0 \\
\hline & $\begin{array}{l}\text { External journal } \\
\text { non peer review }\end{array}$ & 7 & 0 & & 5 & 3 \\
\hline & $\begin{array}{c}\text { International } \\
\text { journal peer } \\
\text { review }\end{array}$ & 4 & 0 & & 8 & 41 \\
\hline & Grey literature & 48 & 0 & & 4 & 7 \\
\hline & No data & 12 & 0 & & 0 & 0 \\
\hline \multicolumn{2}{|c|}{ Diffusion byuniversity (website): } & Yes & $\begin{array}{l}\text { No information o } \\
\text { individual }\end{array}$ & $\begin{array}{l}\text { ublications of } \\
\text { earchers }\end{array}$ & \multicolumn{2}{|c|}{ Yes } \\
\hline
\end{tabular}

Source: own elaboration. The shading was added to help distinguish the categories.

In general, we note that both the universities in San Martin and Cusco do not identify individual publications of their researchers by means of their institutional channels (websites). This can be qualified per se as a limitation to access to international academic circles, since individual productions are simply invisible. For the Universidad San Antonio de Abad de Cusco we mapped publications in the journals published by the university. None of these journals are included in an international ranking, which reduces their international visibility.

Regarding the language of publication, all five selected Andean universities tend to publish in Spanish. This reduces their possibilities of reception in an English-language dominated scientific environment. In the case of the university of San Martin, this holds for all of the research projects $(n=48)$ we have mapped. In the case of the Universidad San Antonio de Abad de Cusco, 103 from the overall 105 publications are written in Spanish $(98 \%)$, although the journals principally also accept contributions in English or Portuguese (we counted one for each of these languages). Over eighty-five per cent of the publications we mapped for UMSA/CIDES (68 from 78; six in English) are written in Spanish. In the case of the publications mapped for the Universidad Nacional de San Marcos only 2 out of 125 
were written in English, all others in Spanish (97\%; one in Portuguese). An exception to this trend is the University of Cuenca in Ecuador where publishing in English is widespread and, in total, equals publishing in Spanish (73 in total, 37 Spanish, 36 English). In the case of the research group on demography we have registered even more publications in English (13) than in Spanish (8).

Second, regarding the topics treated in our compilation, we state a difference among the five Andean universities. The universities of San Martin and Cusco located in the Peruvian provinces (which is every region except Lima) produce mostly knowledge on local phenomena geographically linked to the region where the university is located; only a small number of research projects and corresponding scientific articles relate to topics in the wider geographical region or even neighboring regions. At the Universidad de San Martin de Tarapoto, all research topics $(100 \%, n=48)$ have a local focus. In the case of Universidad San Antonio de Abad in Cusco 39 (37\%) of all articles cover local subjects (Cusco), 25 articles target national phenomena ("in Peru" or in other Peruvian provinces). Together, local and national subjects account for more than $51 \%$ of the articles. Sixteen articles cover international subjects. A further 25 articles cover theoretical or legal topics, and seven of them focus on questions related to indigenous peoples. Given the fact that the region of Cusco ranges as one of the "most indigenous" regions in Peru, this could be interpreted as adding to the production on local phenomena. In contrast, knowledge production at UMSA/CIDES in La Paz, Bolivia and UNSM in Lima, Peru has a rather "national" character, focusing on specific national issues ("in Bolivia" or "in Peru" respectively). At CIDES, $44 \%$ of all publications on issues of sustainability or sustainable development $(n=78)$ have such a national character. Out of these 35 publications, nine target local phenomena, and the rest (69) are concerned with regional or global issues or theoretical discussions. At UNSM in Lima, Peru, 46\% (58) of the publications are national in scope ("in Peru"), and 26 publications have an international scope (40 publications do not specify their geographical focus). The Universidad de Cuenca again acts as an outlier. Although it could be qualified as a non-capital provincial university, the majority of publications (54 from 73: more than 73 per cent) have a national subject ("in Ecuador"). Only 7 publications treat local subjects and 9 cover international subjects (plus three publications on theoretical or methodological issues).

Third, we examined the location of publications. We found that the majority of publications are published by local publishers, in journals edited by the university, or as "grey literature", unmediated by an editorial process. There is a slight variation among the cases. At Universidad San Antonio de Abad in Cusco, all publications displayed by the university's website are published in local journals, which are not listed in international rankings. In the case of UMSA/CIDES in La Paz, Bolivia, almost $69.2 \%(n=78)$ of the publications are featured as books published by local publishers, or articles of local journals. Out of the scientific articles recorded $(n=29), 15$ were published by journals owned by the respective university, one by an Ecuadorian national academic journal, five in international journals without peer review, and only eight in international journals with peer review, but which are not listed in international rankings. Slightly more than 70 per cent are edited in Bolivia (71.8\%).

In the case of UNSM in Lima, Peru, we found mostly grey literature $(n=48 ; 38 \%)$, and books published by national editorials (20 books) followed by articles in national journals (25; only two peer-reviewed, 10 non-peer reviewed own UNSM journals). Of all publications we mapped, $68 \%$ were edited in Peru $(86$, followed by 8 publications printed in Spain and 3 in Mexico). Only four publications appeared in international peer reviewed journals. Moreover, there is a tendency to publish grey literature in the form of simple PDF files uploaded to the respective researchers' internet pages. Again, Universidad de Cuenca takes the role of outlier as more than half of all publications mapped have been published in international peer reviewed journals (41 from 73). The remainder were published in international books (11), national books (10), non-peer-reviewed external journals (3), grey 
literature (7: all of them conference papers), and one non-peer-reviewed journal published by the university itself.

This selective analysis of the features of local knowledge production on sustainability and sustainable development demonstrates that scientific production at these universities suffers from various dimensions of limitations which generate and reproduce the spatially fragmented global knowledge value chains, and severely limit the potential impact of these universities on (regional) sustainability transitions. However, we also find variation here, represented especially by the case of the University of Cuenca, Ecuador, where knowledge production is not limited to local phenomena, and does circulate in wider national and international academic circles. Our mapping does not deliver information on the reasons for this exception. Based in our experience and the cooperation with colleagues from this university, we hypothesize that the specific careers of the academic staff involved in the research groups we mapped may intervene in the outcome. Many researchers have been trained abroad and therefore may be more familiar with publishing in English and in international venues.

\section{Addressing Fragmentations: The Role of International Academic Partnerships}

We argue that international academic partnerships command the potential of bridging the fragmentations of the global knowledge value chain on sustainability. In doing so they can provide more comprehensive sustainability relevant knowledge to the global debates which inform sustainability transitions and they can generate impacts in various places simultaneously. These partnerships can be particularly beneficial for universities from lower income countries. Such partnerships, often framed in term of "development" or, recently, as contributing to the UN 2030 Agenda, have proliferated in recent years. Usually they act as top-down transmission mechanisms for material resources, including stipends, mobility, and capacity building, which flow from North to South. As an additional benefit, structural effects on the educational system as a whole may follow. We emphasize here the possibilities of knowledge brokerage and circulation these partnerships can offer. In this remaining section we present several instruments and methods applied in the frame of an international partnership and intended to address the fragmentations of the global knowledge value chain on sustainability identified in the previous sections.

\section{1. trAndeS: Social Inequalities and Sustainable Development in the Andes}

We draw in this section on our experience with the international academic partnership "trAndeS-Postgraduate Program on Social Inequalities and Sustainable Development in the Andean Region". The program is a joint initiative by the Freie Universität Berlin (FU Berlin) and the Pontificia Universidad Católica del Perú (PUCP; based in Lima). It forms part of a funding line on the implementation of the 2030 UN Agenda and the 17 Sustainable Development Goals (SDGs) financed by the German Ministry of Economic Cooperation and Development (BMZ) and the German Academic Exchange Service (DAAD) [55]. The program is concerned with the persistent and large social inequalities in the Andean region, one of the most unequal regions on earth, and their impact on the opportunities for sustainable development as defined in the 2030 Agenda [56].

Social inequalities in the Andean region which comprises the countries Peru, Bolivia, Ecuador, Chile, Colombia, Venezuela and Northern Argentina are multidimensional and interdependent. Multidimensional and interdependent inequalities are defined as "the distances between positions, which individuals or groups of individuals assume in the context of a hierarchically organized access to relevant social goods (income, wealth, a healthy environment etc.) and power resources (rights, political participation, political positions etc.)" [57]. They are manifest in several dimensions, such as income, wealth, the access to essential (land, water, etc.) and public goods (health, education, security), the opportunities to live in a healthy natural environment, or concerning the endowment of formal and informal rights. Furthermore, inequalities in the Andes are structured along intersecting lines of class, ethnic origin, gender, age, and territory, among other categories. 
Due to its colonial past, particularly the indigenous groups suffer from discrimination and exclusion. Additionally, women as a social group are subject to highly discriminatory social and political practices. Many of the social inequalities affecting the people in the region can be conceived of as interdependent because they result from processes that connect people and spaces asymmetrically from the local to the global levels. Social inequalities in the Andes are, thus, embedded in and shaped by global hierarchies, transnational relations and national, or local negotiations [21]. As explained in Section 2, climate change and international production chains reflect these interdependencies on the global level and their impact in terms of inequalities in the Andes, amongst others.

Because of their multidimensional and interdependent characteristics, inequalities constitute fundamental obstacles to inclusive sustainable development. Many challenges for sustainable development (or human and natural well-being) in the Andean region frequently do not result from resource scarcity or misallocation but from the unequal distribution of resources or the unequal access to them.

Research and training in the context of trAndeS focuses on unearthing the inequalities, particularly the power asymmetries, that underpin current development and sustainability problems in the Andean region, and identifying the actors that cause or suffer from inequalities as well as the mechanisms that produce and reproduce them. The program aims at providing robust information to shape policy decisions intended to mitigate inequalities and thereby promote transitions towards sustainability or sustainable development. In order to reach these objectives, trAndeS implements a program consisting of three pillars: postgraduate training including a scholarship program for MA and doctoral students, interdisciplinary research, and networking in the Andean region in general and between PUCP and FU Berlin in particular.

\subsection{Bridging Disciplinary Boundaries in Research and Teaching on Social Inequalities and Sustainability}

Given the limited consideration of social and political factors in debates on sustainability transitions which we have identified as a major fragmentation of the global knowledge value chain on sustainability, one of the main objectives of the project is to contribute to the debates from an interdisciplinary social science perspective. In order to do so, the trAndeS project team from Germany and Peru has designed a teaching and research program with a strictly inter- and transdisciplinary character.

Regarding teaching, a supplementary interdisciplinary curriculum was set up for MA and Phd students of a series of study programs at PUCP including anthropology, economics, political science, sociology, and human geography and environment. The core of this curriculum forms two compulsory courses that provide basic conceptual, theoretical, and empirical knowledge on the relations (causes and impacts) between social inequalities and sustainable development.

Teaching staff from different disciplines ensure the interdisciplinary character of the curriculum. All of the lecturers invited to the program addressed issues of sustainability and sustainable development from their respective disciplinary position but with a focus on the causes and effects of social inequalities on sustainability. Between 2017-2020 a total of 61 researchers lectured in the two courses offered in 2017 and in 2019. In detail, the two students' cohort of the program (from 2017-2018 and from 2019-2020) received lectures from 14 economists, sixteen sociologists, thirteen political scientists, nine anthropologists, two lecturers from architecture, agricultural engineering, geography, and history and one lecturer from philosophy (Figure 4). 


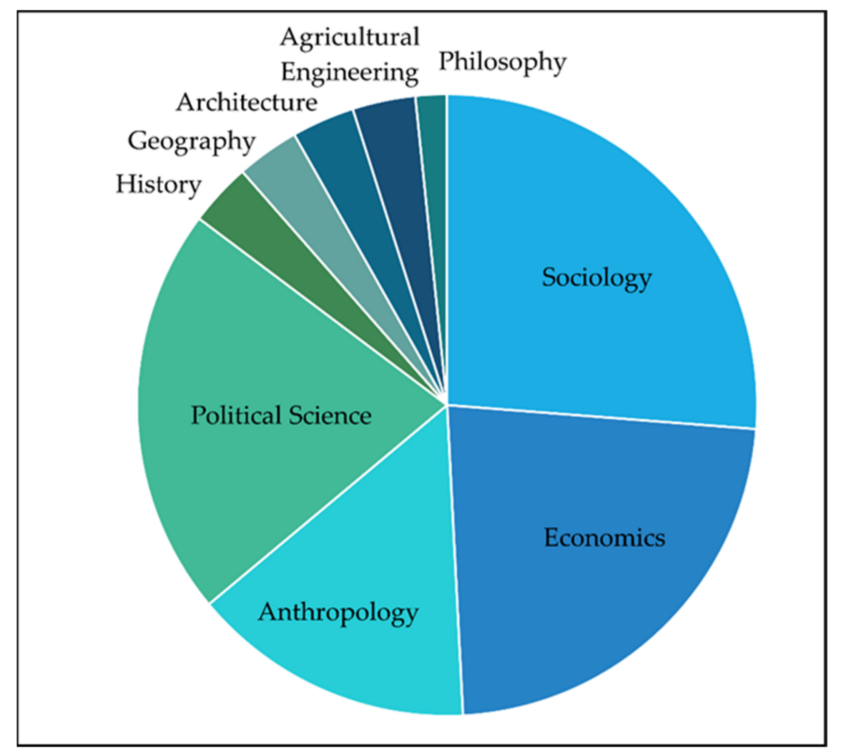

Figure 4. Disciplinary composition of lecturers participating the program trAndeS courses in 2017 and $2019(n=61)$. Source: own elaboration.

Research in the frame of the program is conducted by the group of master's and doctoral scholarship holders and the principal investigators of the project located at PUCP and FU Berlin. Trained in the interdisciplinary curriculum which provides a constant exchange with other disciplines, the MA and PhD students apply these interdisciplinary insights in their own research. This interdisciplinary perspective helped to bring about a wide array of sustainability-relevant investigations which include research topics such as various as the unequal access to water resources in the context of mining projects, gender inequalities regarding indigenous women and young female prison inmates, the adoption and implementation of new environmental rules and of new governance institutions able to generate sustainable development and to contain economic and institutional volatility, and the relationship between development models and social conflicts. To reinforce the interdisciplinary encounter, all junior researchers of the program received supervision and monitoring from academics from different disciplines and universities both individually or in the context of the workshops and conferences organized by the program.

The interdisciplinary perspective is also visible in the composition of active participants (presenters) of the programs' major academic events. Between 2016 and 2019, trAndeS organized eleven events like conferences, workshops, summer schools, and panels at conferences. A total of 217 researchers participated as speakers in these events coming from different social sciences disciplines, most of them from political science (70), sociology (52), anthropology (28), economics (27), and geography (19).

As a program based in the social sciences but concerned with questions regarding the "materiality of nature" [58], we were keen to exchange ideas with the natural sciences and those disciplines traditionally prominent in the discussion on sustainable development and sustainability, in particular in order to integrate socio- ecological inequalities into the programs' research activities (Figure 5). Additionally, the project established contact between the organizational units of FU Berlin and PUCP in charge of promoting mutual learning on issues related to campus sustainability and the role of universities in sustainability transitions. By means of individual guest invitations and workshops in Berlin and Lima, they exchanged experiences and approaches to campus sustainability. The cooperation culminated in the publication of a brochure in which universities from the FU-led University Alliance for Sustainability and five Latin American universities present the pathways of their sustainability initiatives [59]. 


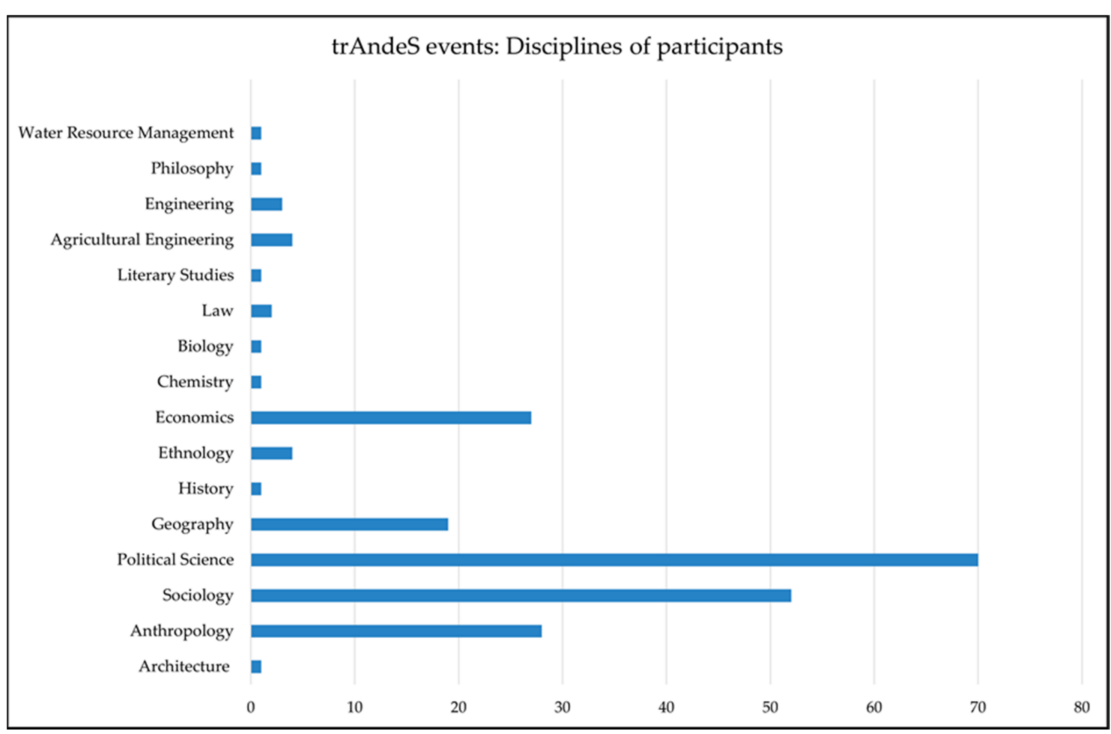

Figure 5. Disciplinary composition of active participants in major academic events organized by trAndeS between 2016 and 2019 (11 events with 217 participants). Source: own elaboration.

\subsection{Adressing Spatial Knowledge Fragmentations: A Hub and a Twodimensional Network}

In order to bridge the spatial knowledge fragmentations, trAndeS promotes a network on two levels. On the global level, the network connects the PUCP, other Andean universities (including local universities in the Peruvian periphery), and the German FU Berlin. The Peruvian university PUCP functions in this network as a hub. It is particularly suited to serve this role, because it is by far the best university in Peru and ranks among the leading universities in the entire region. Due to its Jesuit roots and a commitment to the theology of liberation, and despite being a private university, PUCP stands for a non-profit model of private higher education that considers training and education to be a public good. In this line, the university grants scholarships to talented students and adjusts tuition fees to the income of the parents of students coming from marginal social groups. PUCP also leads a national university network in Peru (Red Peruana de Universidades) which aims at promoting mutual support and greater exchange, particularly with universities outside of the country's capital.

For our project, PUCP serves as a regional hub to irradiate into the Andean region by means of the Trans-Andean Network for Sustainability (hereafter "Red trAndeS"). Red trAndeS is a key instrument to address the spatial fragmentation of knowledge production and diffusion, as it connects researchers from disperse places in the Andean region, and allows them to create regional networks and jointly produce knowledge. For example, in our research workshops, academics from different universities found a space to compare country experiences and exchange knowledge on similar sustainability challenges (e.g., the socio-ecological impact of quinoa and other food productions recently integrated into globalized commodity chains). Furthermore, the project integrates them as scholarship holders (MA and doctoral students), as postdoctoral (visiting) researchers with fellowships, as lecturers in our courses, and as active participants of our academic workshops and conferences.

The two-layer network is designed to overcome the spatial fragmentation of knowledge production and diffusion both at the local and the global levels, and to foster knowledge on the embeddedness of issues of sustainability in global processes. Therefore, it brings researchers from the Andean region and other world regions together. Experts from the network have been involved in the project's teaching activities at PUCP and FU Berlin and in international conferences. trAndeS researchers from PUCP and FU Berlin have offered courses in several Andean (Bolivia, Chile, Ecuador, Colombia) or other Peruvian (Iquitos, San Martín, Cusco, Ayacucho) universities. The regional diversity is shown in Figure 6. In the 11 mayor events trAndeS has organized, researchers participated from 
Argentina (10), Bolivia (10), Ecuador (3), Chile (18), Peru (73), Venezuela (1) and Colombia (8). To foster a global exchange, scholars from North America and Europe also participated in these events.

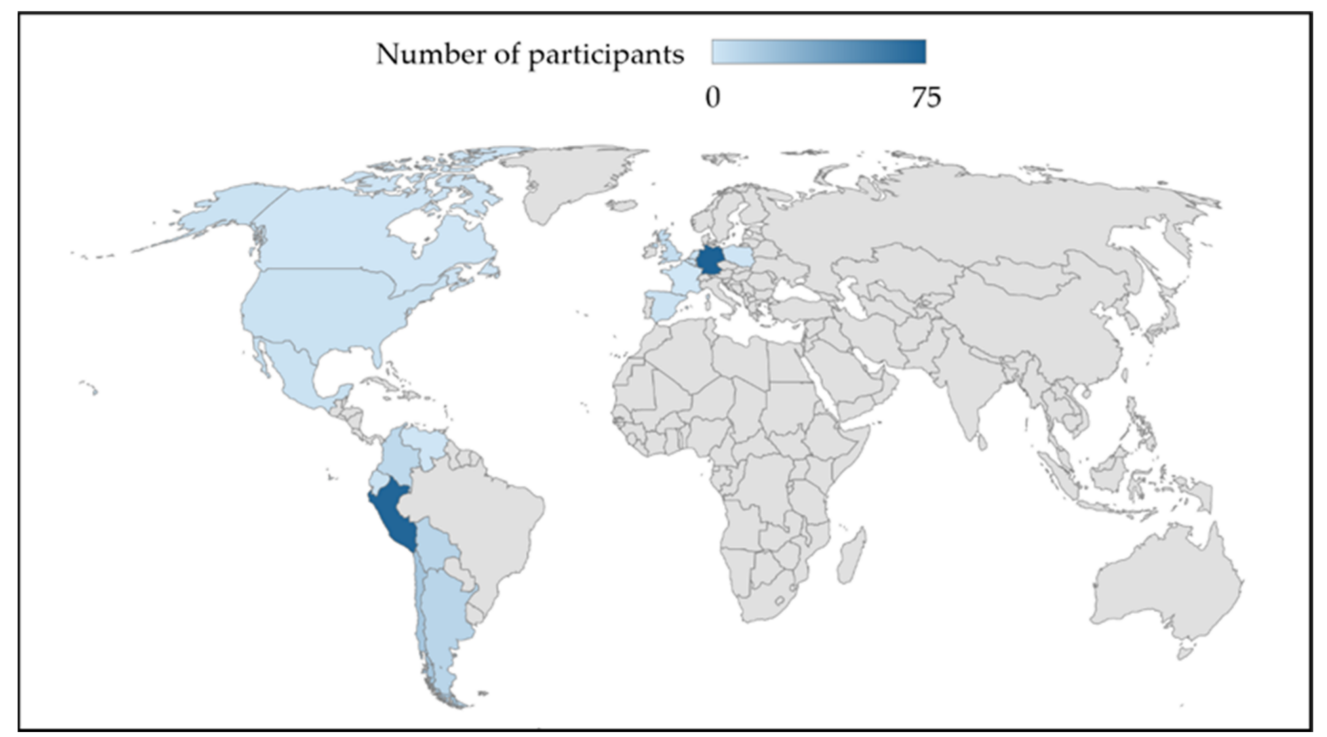

Figure 6. Origin of participants in trAndeS teaching and academic activities. Source: own elaboration.

The networking activities are perceived as very beneficial by the network members from the Andean region. A survey among the scholarship holders and fellows of the program on the impact of their scholarship on their academic career confirms the importance of the network and its bridging function. All respondents rated the expansion of their regional and global networks as the most important outcome of the scholarship. Likewise, they stressed the positive effect the network and its activities had on the expansion of their scientific production and the topics they study (Figure 7).

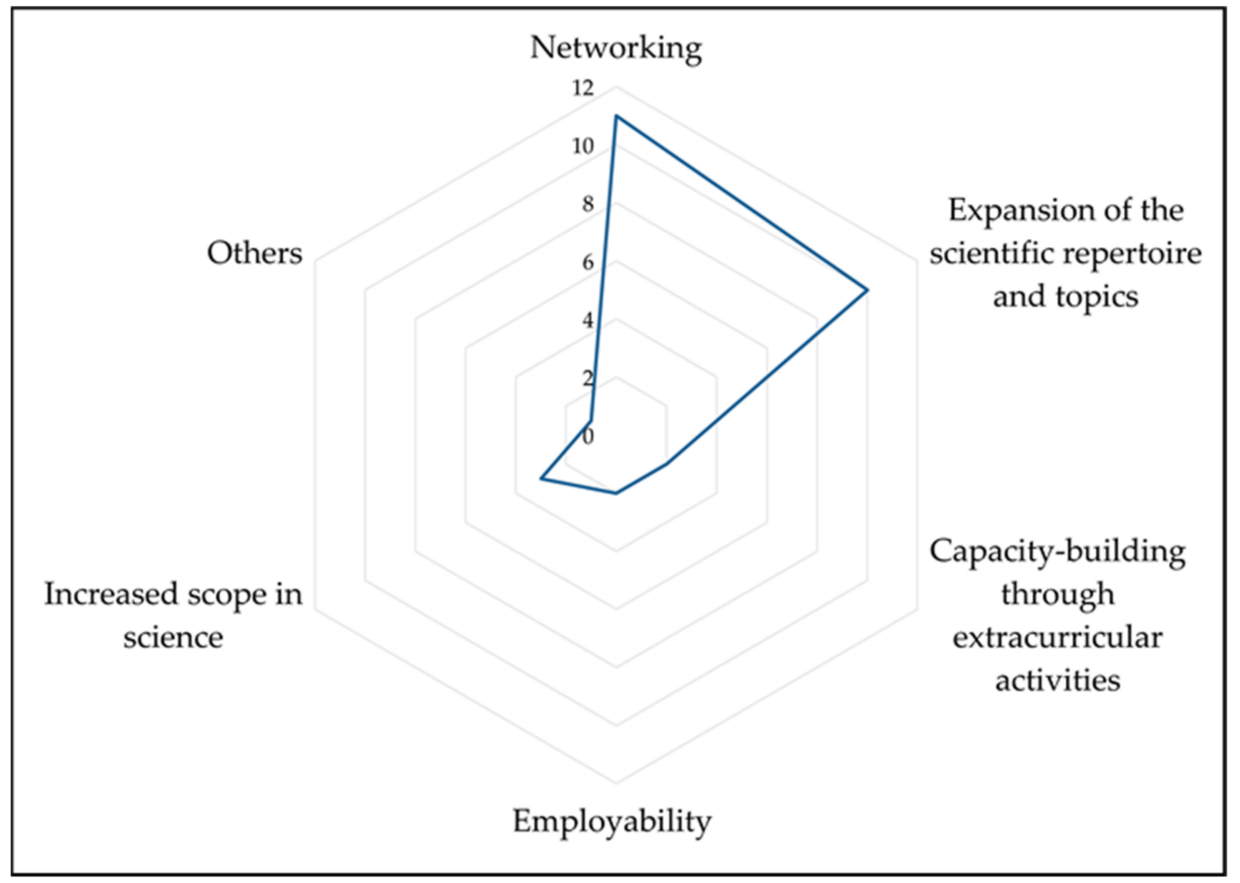

Figure 7. trAndeS grant holders' responses to the question, "To what extent have the activities and training offered by the trAndeS program contributed to your professional career?". Source: own elaboration. 
The network also serves as a platform for new joint academic initiatives and transdisciplinary activities. In particular, and since debates around inequality and sustainability are of utmost societal relevance, the Red trAndeS promotes transdisciplinary cooperation and the exchange of ideas between researchers, academic institutions, civil society organizations, development organizations, and other actors or networks with activities related to sustainable development. In this line, we have been holding a series of academic events at different locations of the Andean region beyond Lima (i.e., in La Paz/Bolivia, Cuenca/Ecuador, and Santiago de Chile/Chile), and we have been fostering transdisciplinary activities connecting research with policy advice and bringing into discussion different knowledge producers, such as academics, think tanks, policy makers, and development cooperation and civil society actors (e.g., the NGO Red Muqui in Peru and the NGO Ciudadanía in Bolivia; representatives of ministries and regulatory or administrative bodies (such as the Peruvian Environmental Ministry) the German Society for International Cooperation (GIZ), German political foundations such as Friedrich Ebert Stiftung (FES) and Konrad Adenauer Stiftung (KAS), and UN organizations such as Economic Commission for Latin America and the Caribbean (ECLAC) and the UN-Research Institute for Social Development (UNRISD)).

Finally, as part of its efforts to bridge global and local knowledge, the network makes its teaching material publicly available. This concerns especially the key courses on concepts of multiple inequalities and sustainability, and its application to the Andean region, and additional smaller courses on these issues from different disciplinary perspectives and methodological approaches. The network also published a series of working papers and policy briefs in English and Spanish, as an outcome of the research by scholarship holders and other network members [60].

\section{Final Reflections}

Universities have been highlighted as important promotors of sustainability not only in research, but also as "living labs" where sustainability innovations can be developed and tested. Their role usually is seen to range from the sustainable managing of their own campus, to teaching, training, interdisciplinary research, and outreach to the community and to non-academic political, economic, and societal actors. Only recently, universities have come into focus as actors promoting sustainability by means of internationalization. In this paper we add to this new strand of research by emphasizing a specific property of international academic partnerships only seldomly discussed: their ability to address disciplinary and geographical barriers in the global debates on how transitions towards sustainability can be achieved.

We build our argument around the concept of the "global knowledge value chain" related to sustainability which we understand as an ideal-typical global network bringing insights from different disciplines and locations into a fruitful encounter with the objective of comprehensively informing sustainability transitions. However, we argue that in practice, this chain exhibits at least two fragmentations that diminish its potential to comprehensively inform sustainability transitions: a disciplinary and a spatial one.

Regarding the first, debates on sustainability often neglect the importance of economic, social, and political factors. As illustrated by the findings in the Web of Science database, the Social Sciences in general and in particular critical works on so called "brown issues" like poverty and social inequalities only seldomly feed into the global knowledge value chain on sustainability.

The second, spatial fragmentation, consists of barriers that exclude specific territories and actors from participation in the global knowledge value chain. The empirical exploration of publishing activities of marginalized universities in the Andean region confirms this kind of barrier.

In this paper, we argue that international academic partnerships can address and contribute to reducing these fragmentations and thereby reinforce the global quest for the promotion of more sustainable ways of living. In particular, they can foster the production 
of more comprehensive, interdisciplinary, and multi-spatial knowledge to inform sustainability transitions. This is especially important to tackle sustainability problems rooted in the different layers of globalization. Likewise, they generate a much wider impact by informing sustainability transitions in various places at the same time.

International partnerships may be particularly beneficial for universities in countries of the Global South as these tend to be excluded from the global debates on sustainability, while at the same time, the Global South is more affected by sustainability challenges rooted in global interdependencies. As our examples of the asymmetric distribution of causes and consequences of climate change and the impact of mitigation measures, and the similarly asymmetric distribution of costs and benefits of global commodity chains illustrate, transitions towards sustainability in a globalized world can only materialize when the global interdependencies of specific phenomena on the local and regional levels are taken into account. Here, the knowledge production of these universities is not peripheral. Deeply rooted in local knowledge networks, their academic production provides key information for local problems of sustainability, which are fundamental to understand the causal relationships underlying global (un-)sustainability. Hence, partnerships between locally embedded and internationally networked universities which explicitly address these fragmentations in knowledge production are cornerstones for global partnerships for promoting sustainability.

Drawing on our international university partnership trAndeS, we presented several instruments and methods intended to address the fragmentations of the global knowledge value chain related to sustainability, such as the interdisciplinary approach towards sustainability within the social sciences (including economics) with a focus on the "brown issues" in our teaching and research activities. Likewise, we stressed the role of our Peruvian partner PUCP as a hub for a regional network, bringing in a broad range of HEI in remote areas of the Andean region.

We close this section with two brief reflections: First, research on sustainability transitions is a fundamental step, but to make an actual change, the adequate policy transfer of knowledge and its application require dense and complex interactions between academia, policy makers, local communities, and economic actors. This topic is beyond the reach of this article. However, international partnerships can again be beneficial. For example, in many Latin American universities, community relations have a much higher status and the instruments used are far more elaborated than in many universities in industrialized countries of the Global North. Partnerships could help establish a fruitful encounter, especially for the latter ones.

Secondly, our arguments carry some policy recommendations: Public policies should acknowledge and reinforce the important role of Higher Education in the promotion of sustainability transitions, not only locally or regionally but also globally. This should include a closer interaction between universities and public entities concerned with sustainable development and international relations, and those in charge of the Higher Education sector. This also requires international development cooperation to include academic actors of the Global South in their networks, their partnerships, and last but not least in their funding strategies and concepts. In general, public policies should support universities' international partnerships by providing reasonable funding lines and programs and creating the conditions for fruitful and long-term exchange among universities located in different parts of the world, particularly with those lacking resources to participate in the global knowledge value chain on sustainability. Public support should also include the search for new and innovative ways of knowledge circulation and adaption between academia and public policy actors. It requires highly specific incentives and institutional and financial support to ensure that the findings and results of these international partnerships can be applied and effectively contribute to a more sustainable world.

Author Contributions: Conceptualization and methodology, B.S. (Bettina Schorr), M.B., B.F. and B.S. (Brigitta Schütt); visualization, B.S. (Bettina Schorr) and B.F.; writing-original draft preparation, 
B.S. (Bettina Schorr); writing-review and editing, B.S. (Bettina Schorr), M.B., B.F. and B.S. (Brigitta Schütt); All authors have read and agreed to the published version of the manuscript.

Funding: We thank the German Academic Exchange Service (DAAD) and the German Ministry for Economic Cooperation and Development (BMZ), who provide funds for the trAndeS_-Programa de Posgrado en Desarrollo Sostenible y Desigualdades Sociales. We also acknowledge financial support by the German Science Foundation and the Open Access Publication Fund of the Freie Universität Berlin.

Institutional Review Board Statement: Not applicable.

Informed Consent Statement: Not applicable.

Acknowledgments: We thank our colleagues from PUCP Peru who provided valuable insights and expertise that greatly assisted this study: Gerardo Damonte, Narda Henríquez, and Ana Sabogal. We are also very grateful for the assistance provided by our students in the preparation of the article: Joana Stalder, Tim Hunzicker, Sophie Vey, and Adrian Pusch. We appreciate the support by Sebastián Huneeus in the literature research and thank Paul Talcott for editing the article. The publication of this article was funded by Freie Universität Berlin.

Conflicts of Interest: The authors declare no conflict of interest. The funders had no role in the design of the study; in the collection, analyses, or interpretation of data; in the writing of the manuscript, or in the decision to publish the results.

\section{References and note}

1. Kahle, J.; Risch, K.; Wanke, A.; Lang, D. Strategic Networking for Sustainability: Lessons Learned from Two Case Studies in Higher Education. Sustainability 2018, 10, 4646. [CrossRef]

2. Caniglia, G.; Luederitz, C.; Groß, M.; Muhr, M.; John, B.; Withycombe Keeler, L.; von Wehrden, H.; Laubichler, M.; Wiek, A.; Lang, D. Transnational Collaboration for Sustainability in Higher Education: Lessons from a Systematic Review. J. Clean. Prod. 2017, 168, 764-779. [CrossRef]

3. Karatzoglou, B. An in-depth literature review of the evolving roles and contributions of universities to education for sustainable development. J. Clean. Prod. 2013, 49, 44-53. [CrossRef]

4. Leal Filho, W.; Will, M.; Shiel, C.; Paço, A.; Farinha, C.S.; Orlovic Lovren, V.; Avila, L.V.; Platje, J.; Sharifi, A.; Vasconcelos, C.R.P.; et al. Towards a Common Future: Revising the Evolution of University-Based Sustainability Research Literature. Int. J. Sustain. Dev. World Ecol. 2021, 503-517. [CrossRef]

5. $\quad$ Leal Filho, W.; Salvia, A.L.; Pretorius, R.W.; Brandli, L.L.; Manolas, E.; Alves, F.; Azeiteiro, U.; Rogers, J.; Shiel, C.; Do Paco, A. (Eds.) Universities as Living Labs for Sustainable Development: Supporting the Implementation of the Sustainable Development Goals; Springer International: Berlin/Heidelberg, Germany, 2020.

6. $\quad$ Leal Filho, W.; Shiel, C.; Paço, A.; Mifsud, M.; Ávila, L.V.; Brandli, L.L.; Molthan-Hill, P.; Pace, P.; Azeiteiro, U.M.; Vargas, V.R.; et al. Sustainable Development Goals and Sustainability Teaching at Universities: Falling behind or Getting Ahead of the Pack? J. Clean. Prod. 2019, 232, 285-294. [CrossRef]

7. Wiek, A.; Withycombe, L.; Redman, C.L. Key Competencies in Sustainability: A Reference Framework for Academic Program Development. Sustain. Sci. 2011, 6, 203-218. [CrossRef]

8. Lozano, R. A Tool for a Graphical Assessment of Sustainability in Universities (GASU). J. Clean. Prod. 2006, 14, 963-972. [CrossRef]

9. Veiga Ávila, L.; Beuron, T.A.; Brandli, L.L.; Damke, L.I.; Pereira, R.S.; Klein, L.L. Barriers to Innovation and Sustainability in Universities: An International Comparison. Int. J. Sustain. High. Educ. 2019, 20, 805-821. [CrossRef]

10. Akins, E.; Giddens, E.; Glassmeyer, D.; Gruss, A.; Kalamas Hedden, M.; Slinger-Friedman, V.; Weand, M. Sustainability Education and Organizational Change: A Critical Case Study of Barriers and Change Drivers at a Higher Education Institution. Sustainability 2019, 11, 501. [CrossRef]

11. Wals, A. Sustainability in higher education in the context of the UN DESD: A review of learning and institutionalization processes. J. Clean. Prod. 2014, 62, 8-15. [CrossRef]

12. Lozano, R.; Lukman, R.; Lozano, F.J.; Huisingh, D.; Lambrechts, W. Declarations for Sustainability in Higher Education: Becoming Better Leaders, through Addressing the University System. J. Clean. Prod. 2011, 48, 10-19. [CrossRef]

13. Hopff, B.; Nijhuis, S.; Verhoef, L.A. New Dimensions for Circularity on Campus-Framework for the Application of Circular Principles in Campus Development. Sustainability 2019, 11, 627. [CrossRef]

14. Velazquez, L.; Munguia, N.; Platt, A.; Taddei, J. Sustainable University: What Can Be the Matter? J. Clean. Prod. 2006, 14, 810-819. [CrossRef]

15. Zilahy, G.; Huisingh, D.; Melanen, M.; Phillips, V.D.; Sheffy, J. Roles of Academia in Regional Sustainability Initiatives: Outreach for a More Sustainable Future. J. Clean. Prod. 2009, 17, 1053-1056. [CrossRef]

16. Pundt, H.; Heilmann, A. Building Collaborative Partnerships: An Example of a 3rd Mission Activity in the Field of Local Climate Change Adaptation. In Universities as Living Labs for Sustainable Development: Supporting the Implementation of the Sustainable 
Development Goals; Leal Filho, W., Salvia, A.L., Pretorius, R.W., Brandli, L.L., Manolas, E., Alves, F., Azeiteiro, U., Rogers, J., Shiel, C., Do Paco, A., Eds.; Springer International Publishing: Cham, Switzerland, 2020; pp. 621-636. [CrossRef]

17. Withycombe, L.; Beaudoin, F.; Lerner, A.; John, B.; Beecroft, R.; Tamm, K.; Wiek, A.; Lang, D. Transferring Sustainability Solutions across Contexts through City-University Partnerships. Sustainability 2018, 10, 2966. [CrossRef]

18. Radinger-Peer, V.; Pflitsch, G. The Role of Higher Education Institutions in Regional Transition Paths Towards Sustainability. Rev. Reg. Res. 2017, 37, 161-187. [CrossRef]

19. Withycombe, L.; Wiek, A.; Lang, D.J.; Yokohari, M.; van Breda, J.; Olsson, L.; Ness, B.; Morato, J.; Segalàs, J.; Martens, P.; et al. Utilizing International Networks for Accelerating Research and Learning in Transformational Sustainability Science. Sustain. Sci. 2016, 11, 749-762. [CrossRef]

20. Berchin, I.I.; Sima, M.; de Lima, M.A.; Biesel, S.; dos Santos, L.P.; Ferreira, R.V.; de Andrade Guerra, J.B.S.O.; Ceci, F. The Importance of International Conferences on Sustainable Development as Higher Education Institutions' Strategies to Promote Sustainability: A Case Study in Brazil. J. Clean. Prod. 2018, 171, 756-772. [CrossRef]

21. Jelin, E.; Motta, R.; Costa, S. (Eds.) Global Entangled Inequalities: Conceptual Debates and Evidence from Latin America; Taylor and Francis: London, UK, 2017.

22. United Nations Development Programme (UNDP). Human Development Report: Sustainability and Equity: A Better Future for All; United Nations Development Programme (UNDP): New York, NY, USA, 2011. Available online: http://hdr.undp.org/sites/ default/files/hdr_2011_en_summary.pdf (accessed on 25 February 2021).

23. Chancel, L.; Piketty, T. Carbon and Inequality: From Kyoto to Paris-Trends in the Global Inequality of Carbon Emissions (1998-2013) E Prospects for an Equitable Adaption Fund; Paris School of Economics: Paris, France, 2015.

24. Göbel, B.; Góngora Mera, M.E.; Ulloa Cubillos, A. (Eds.) Desigualdades Socioambientales en América Latina; Universidad Nacional de Colombia: Bogotá, Colombia; Ibero-Amerikanisches Institut: Berlin, Germany, 2014.

25. Ströbele-Gregor, J. Lithium in Bolivien: Das Staatliche Lithium-Programm, Szenarien Sozio-Ökologischer Konflikte und Dimensionen Sozialer Ungleichheit; desiguALdades.net Working Paper Series No. 13; desiguALdades.net International Research Network on Interdependent Inequalities in Latin America: Berlin, Germany, 2012. Available online: https:/ /www.desigualdades.net/ Resources/Working_Paper/13_WP_Str_bel_Gregor_online_dt.pdf (accessed on 16 February 2021).

26. Dietz, K.; Prause, L. Die sozial-ökologischen Folgen der E-Mobilität. Konflikte um den Rohstoffabbau im Globalen Süden. In Baustelle Elektromobilität: Sozialwissenschaftliche Perspektiven auf die Transformation der (Auto-) Mobilität; Brunnengräber, A., Haas, T., Eds.; Transcript Verlag: Bielefeld, Germany, 2020; pp. 329-354, Similar situations can be found in the cases of copper and cobalt mining.

27. Plank, L.; Staritz, C. Introduction: Global Commodity Chains and Production Networks-Understanding Uneven Development in the Global Economy. J. Entwickl. 2009, 25, 4-19. [CrossRef]

28. Kaplinsky, R. Globalization, Poverty and Inequality; Polity Press: Cambridge, UK, 2005.

29. Bridge, G. Global Production Networks and the Extractive Sector: Governing Resource-based Development. J. Econ. Geo. 2008, 8, 289-419. [CrossRef]

30. Bustos Gallardo, B.; Prieto, M.; Barton, J. Ecología Política en Chile: Naturaleza, Propiedad, Conocimiento y Poder; Edicion Universitaria: Santiago, Chile, 2015.

31. Bebbington, A.; Humphreys Bebbington, D.; Bury, J.; Lingan, J.; Muñoz, J.P.; Scurrah, M. Mining and Social Movements: Struggles Over Livelihood and Rural Territorial Development in the Andes. World Dev. 2008, 36, 2888-2905. [CrossRef]

32. Damonte, G.; Boelens, R. Hydrosocial Territories, Agro-export and Water Scarcity: Capitalist Territorial Transformations and Water Governance in Peru's Coastal Valleys. Water Int. 2019, 44, 206-223. [CrossRef]

33. Damonte, G.; Dominguez, I.; Muñoz, I.; Oré, M.T. Escasez de agua en la cuenca del río Ica y el Alto Pampas en Huancavelica: Un intento de mirada interdisciplinaria. In Aguas en Disputa: Ica y Huancavelica Entre el Entrampamiento y el Diálogo; Oré, M.T., Muñoz, I., Eds.; Fondo Editorial, Pontificia Universidad Católica del Perú: Lima, Peru, 2018; pp. 47-74.

34. Castillo, M. Socio-Ecological Inequality and Water Crisis: Views of Indigenous Communities in the Alto Loa Area. Environ. Justice 2016, 9, 9-14. [CrossRef]

35. Bebbington, A.; Bury, J. Subterranean Struggles: New Dynamics of Mining, Oil, and Gas in Latin America; University of Texas Press: Austin, TX, USA, 2013.

36. Paredes, M. La Transnacionalización de la Resistencia a la Minería en Tambogrande y Pascua Lama. Am. Lat. Hoy 2019, 80, 73-94. [CrossRef]

37. Paredes, M. Conflictos mineros en el Perú: Entre la protesta y la negociación. Debates Sociología 2019, 5-32. [CrossRef]

38. Schorr, B. Oportunidades desiguales: Empresas y Estado en conflictos sobre la minería en Chile. Estud. Atacameños 2018, 239-255. [CrossRef]

39. Dietz, K.; Engels, B. Contested Extractivism, Society and the State: An Introduction. In Contested Extractivism, Society and the State: Struggles over Mining and Land; Engels, B., Dietz, K., Eds.; Palgrave Macmillan UK: London, UK, 2017; pp. 1-19.

40. Magrach, A.; Sanz, M.J. Environmental and Social Consequences of the Increase in the Demand for 'Superfoods' World-wide. People Nat. 2020, 2, 267-278. [CrossRef]

41. Sommaruga, R.; Eldridge, H.M. Avocado Production: Water Footprint and Socio-economic Implications. EuroChoices 2021. [CrossRef] 
42. McDonell, M. The Quinua Boom Goes Bust in the Andes, NACLA-Report on the Americas. 2018. Available online: https: //nacla.org/news/2018/03/12/quinoa-boom-goes-bust-andes (accessed on 13 July 2021).

43. Gereffi, G.; Fernandez-Stark, K. Global Value Chain Analysis: A Primer; Duke University: Durham, NC, USA, 2011 ; p. 4.

44. Saliola, F.; Zanfei, A. Multinational Firms, Global Value Chains and the Organization of Knowledge Transfer. Res. Policy 2009, 38, 369-381. [CrossRef]

45. Boström, M. A Missing Pillar? Challenges in Theorizing and Practicing Social Sustainability: Introduction to the Special Issue. Sustain. Sci. Pract. Policy 2012, 8, 3-14. [CrossRef]

46. Boyer, R.; Peterson, N.; Arora, P.; Caldwell, K. Five Approaches to Social Sustainability and an Integrated Way Forward. Sustainability 2016, 8, 878. [CrossRef]

47. Only recently, the literature on sustainability transitions has taken up the impact of these factors which are generally explored by the Social Sciences, see Köhler, J.; Geels, F.W.; Kern, F.; Markard, J.; Onsongo, E.; Wieczorek, A.; Alkemade, F.; Avelino, F.; Bergek, A.; Boons, F. An Agenda for Sustainability Transitions Research: State of the Art and Future Directions. Environ. Innov. Soc. Transit. 2019, 31, 1-32.

48. Allouche, J.; Middleton, C.; Gyawali, D. Technical Veil, Hidden Politics: Interrogating the Power Linkages behind the Nexus. Water Altern. 2015, 8, 610-626.

49. For the case of Latin America:; Orellana, V. Current Situation and Challenges of Higher Education in Latinamerica and the Caribbean, Notes Education and Development Post-2015; UNESCO: Santiago, Chile, 2014. Available online: http://www.unesco.org/new/ fileadmin/MULTIMEDIA/FIELD/Santiago/pdf/APUNTE06-ENG.pdf (accessed on 13 July 2021).

50. Hanauer, D.I.; Sheridan, C.L.; Englander, K. Linguistic Injustice in the Writing of Research Articles in English as a Second Language: Data from Taiwanese and Mexican Researchers. Writ. Commun. 2019, 36, 136-154. [CrossRef]

51. Ammon, U. Linguistic Inequality and its Effects on Participation in Scientific Discourse and on Global Knowledge Accumulation: With a Closer Look at the Problems of the Second-rank Language Communities. Appl. Linguist. Rev. 2012, 3, 333-355. [CrossRef]

52. Ferguson, G. The Global Spread of English, Scientific Communication and ESP: Questions of Equity, Access and Domain Loss. Ibérica 2007, 13, 7-38.

53. Agyeman, J.; Bullard, R.D.; Evans, B. Exploring the Nexus: Bringing Together Sustainability, Environmental Justice and Equity. Space Polity 2002, 6, 77-90. [CrossRef]

54. Fukuda-Parr, S. From the Millennium Development Goals to the Sustainable Development Goals: Shifts in Purpose, Concept, and Politics of Global Goal Setting for Development. Gend. Dev. 2016, 24, 43-52. [CrossRef]

55. In This Line, Seven DAAD SDG Graduate Schools Are Funded, in Which German Universities Are Partnering with Universities in Latin America (Peru and Colombia), Asia (Vietnam) and Africa (Ethiopia, West Africa, Cameroon, South Africa). Available online: https: / / www.programa-trandes.net/en/SDG-Graduate-Schools/index.html (accessed on 23 June 2021).

56. Schorr, B. How Social Inequality Affect Sustainable Development: Five Causal Mechanisms Underlying the Nexus; trAndeS Working Paper Series No. 1; Lateinamerika-Institut, Freie Universität Berlin: Berlin, Germany, 2018. Available online: https://www. programa-trandes.net/Ressources/working_papers/WP-1-Schorr-Online.pdf (accessed on 16 February 2021).

57. Braig, M.; Costa, S.; Göbel, B. Social Inequalities and Global Interdependencies in Latin America: A Provisional Appraisal; desiguALdades.net Working Paper Series No. 100; desiguALdades.net International Research Network on Interdependent Inequalities: Berlin, Germany, 2016. Available online: https:/ / refubium.fu-berlin.de/bitstream/handle/fub188/22070/WP-100-Braig-CostaGoebel-Online.pdf?sequence=1\&isAllowed=y (accessed on 16 February 2021).

58. Dietz, K. Researching Inequalities from a Socio-ecological Perspective. In Global Entangled Inequalities: Conceptual Debates and Evidence from Latin America; Jelin, E., Motta, R., Costa, S., Eds.; Taylor and Francis: London, UK, 2017; pp. 76-92.

59. trAndeS; University Alliance for Sustainability. Universities as Change Makers: Sustainability Initiatives from across the Globe; University Alliance for Sustainability; trAndeS-Postgraduate Program on Sustainable Development and Social Inequalities in the Andean Region: Berlin, Germany, 2020.

60. Available online: https://www.programa-trandes.net/en/publication/index.html (accessed on 30 June 2021). 